\title{
Serum Magnesium in Pre-eclampsia and Eclampsia
}

\author{
NAHAR K, YASMIN H, SHAMSUDDIN L
}

\begin{abstract}
Objective: To assess the serum magnesium level of pregnant women with pre-eclampsia and eclampsia in Mymensingh Medical College \& Hospital (MMCH).

Materials and Methods: This descriptive cross-sectional study was carried out in the department of Obstetrics and Gynaecology of Mymensingh Medical College \& Hospital (MMCH) and "Prof. Muhammed Hossain Central Laboratory" of Bangladesh Agricultural University (BAU). The serum magnesium level were estimated in 60 study subjects who were pregnant women with pre-eclampsia \& eclampsia and of 60 control subjects who were the normotensive pregnant women by photometric test using xylidyl blue.
\end{abstract}

Results: The mean ( $\pm S D)$ serum magnesium of the control and study group were $(2.29 \pm 0.28$ $\mathrm{mg} / \mathrm{dl})$ \& $(1.84 \pm 0.26 \mathrm{mg} / \mathrm{dl})$ respectively. The difference in serum magnesium level between the two groups was statistically highly significant $(p=<0.001)$. In the study group the mean $( \pm S D)$ serum magnesium level of the pre-eclamptic \& eclamptic groups were $(1.9150 \pm 0.26$ $\mathrm{mg} / \mathrm{dl})$ \& $(1.8063 \pm 0.25 \mathrm{mg} / \mathrm{dl})$ respectively and the difference between them was also statistically significant $(p=<0.05)$.

Conclusion: From the result it could be concluded that hypomagnesaemia can be said to be one of the etiological factors in pre-eclampsia and eclampsia. Hence by estimating serum magnesium during antenatal period pre-eclampsia can be predicted and eclampsia can be prevented early.

Key words: Pre-eclampsia, Eclampsia, Serum magnesium.

\section{Introduction:}

Hypertension complicates as many as 5-8\% of all pregnancy. Among the hypertensive disorders of pregnancy the highest risks are associated with preeclampsia \& eclampsia. ${ }^{1}$ They are one of the most common causes of maternal \& fetal mortality \& morbidity. But the exact etiology of pre-eclampsia \& eclampsia is still unknown. Now-a-days eclampsia is considered as malnutrition related disease. In Bangladesh eclampsia accounts $5 \%$ of total obstetric admission in our health facilities \& $16 \%$ of maternal death. ${ }^{2}$

It has been demonstrated that magnesium is essential for life ${ }^{3}$. Magnesium is the second most abundant intracellular cation \& the fourth most abundant cation in the body. Over 300 enzymes are dependent on magnesium ${ }^{4}$.

The principal clinical features attributed to magnesium deficiency are irritability, tetany, hyperreflexia, \& occasionally hyporeflexia 5 . Serum magnesium level is tightly regulated in a narrow range of approximately 0.7 to $1.0 \mathrm{~m} \mathrm{~mol} / \mathrm{L}$ because only $1 \%$ of the total body content of magnesium is extracelluler. Magnesium deficiency is identified when serum ionized magnesium level falls below $0.7 \mathrm{~m} \mathrm{~mol} / \mathrm{L}$ although patients remain asymptomatic. Symptoms appear when level falls below $0.5 \mathrm{~m} \mathrm{~mol} / \mathrm{L}^{2}$.

Serum magnesium progressively declined during pregnancy reaching a nadir at 34 weeks and then rises up to term ${ }^{6}$. Statistically significant fall in serum magnesium has been observed in pre-eclampsia \& eclampsia. In eclampsia serum magnesium was markedly reduced than in pre-eclampsia. Administration of magnesium sulfate to these patients were beneficial in relieving severity of the disease ${ }^{7}$. One study showed that abnormally low concentration of ionized magnesium in the serum is responsible for eclamptic convulsion ${ }^{2}$.

1 Associate Professor, Department of Obs. \& Gynae, Mymensingh Medical College

2. Consultant, Department of Obs. \& Gynae, Sherpur

3. Professor, Department of Obs. \& Gynae, Enam Medical College 
Magnesium has been established as an essential element for fetal well-being. Its deficiency during pregnancy has been reported to be associated with eclampsia, pre-eclampsia, preterm birth, increased maternal hospitalization, incidence of low birth weight $\&$ small for gestational age infants. ${ }^{8}$

So there is a relation between the low level of serum magnesium of pregnant women \& the development of pre-eclampsia \& eclampsia. Supplementation of these elements to diet may be of value to prevent preeclampsia \& eclampsia. Oral magnesium supplementation during pregnancy improves the maternal morbidity \& mortality \& also improves the fetal outcome ${ }^{8}$.

\section{Materials and Methods:}

This descriptive cross sectional study was carried out from July 2009 to June 2010 in the Department of Obstetrics \& Gynaecology, Mymensingh Medical college Hospital \& Prof. Muhammed Hussain Central Laboratory", BAU. Among the admitted patient total 120 was taken with proper selection criteria. Of which 60 were the study subjects (pregnant women with pre-eclampsia \& eclampsia) and 60 were control subjects (the normotensive pregnant women).

Assessment of serum magnesium is done in this study by photometric test using xylidyl blue. Patients were diagnosed as case and control by history, appropriate clinical examination and urine albumin test by heat coagulation test.

In each case, information about the patients were recorded in structured questionnaire after obtaining written consent of the patients/guardians in the consent form. $5 \mathrm{ml}$ of venous blood was collected from each subject (both study and control group) with all aseptic precautions using sterile disposable plastic syringe by anticubital venipuncture and poured into a clean glass test tube. The collected blood was allowed to clot at room temperature. Fluid was separated by centrifugation for 10 minutes. The sera obtained by centrifuging were kept in eppendrofs tube after proper labeling. Maternal serum magnesium level was categorized into three groups- one group having serum magnesium level of $<1.8 \mathrm{mg} / \mathrm{dl}$. Next group having serum magnesium level of $1.8 \mathrm{mg} / \mathrm{dl}$ \& another group having serum magnesium level of $>1.8 \mathrm{mg} / \mathrm{dl}$. Calculated data were arranged in systemic manner, presented in various tables and figures. Statistical analysis was made to evaluate the objectives of this study with the help of Statistical Package for Social Science (SPSS, Version 11.5). Level of significance was expressed as $P$ value. $P$ value $<0.05$ was considered as significant.

\section{Results}

The patient characteristics as mean maternal age, parity, mean gestational age and mean economic status are shown in table I. The result showed that statistically very significant $(P<0.01)$ difference in case of antenatal care status between the two groups in table II. The highest (82\%) of study group have no antenatal care. Only $67 \%$ of control group have regular antenatal care. Highest number of patient was observed having systolic BP (140-160 $\mathrm{mm}$ of $\mathrm{Hg}$ ) and diastolic BP (90-100 mm of $\mathrm{Hg}$ ). Second highest number $23 \%$ having systolic BP $(161-200 \mathrm{~mm}$ of $\mathrm{Hg})$ and about $17 \%$ having diastolic BP above $110 \mathrm{~mm}$ of $\mathrm{Hg}$ (figure I).

Table-1

Patient characteristics of the case \& the control group:

\begin{tabular}{llll}
\hline Variables & $\begin{array}{l}\text { Case }(\mathrm{n}=60) \\
(\text { Mean } \pm S D)\end{array}$ & $\begin{array}{l}\text { Control }(\mathrm{n}=60) \\
(\text { Mean } \pm S D)\end{array}$ & P value \\
\hline Age (years) & $25.35 \pm 6.19$ & $25.33 \pm 4.27$ & 0.985517 \\
Monthly income & $3500.00 \pm 95.00$ & $7500.00 \pm 250.00$ & 0.415 \\
Parity & $1.22 \pm 1.40$ & $0.85 \pm 1.17$ & 0.0858 \\
Gestational age & $35.00 \pm 20.14$ & $38.00 \pm 18.42$ & $0.0017^{\text {** }}$ \\
\hline
\end{tabular}

Data were analyzed using unpaired students 't' test 
Table II

Distribution (\%) of the respondent by antenatal care status:

\begin{tabular}{lcc}
\hline Antenatal care & $\begin{array}{c}\text { Control } \\
(\mathrm{N}=60)\end{array}$ & $\begin{array}{c}\text { Study } \\
(\mathrm{N}=60)\end{array}$ \\
\hline Regular & $40(66.67)$ & $08(13.33)$ \\
Irregular & $10(16.67)$ & $03(5.00)$ \\
No & $10(16.67)$ & $49(81.67)$ \\
All & 100.00 & 100.00 \\
P value & 0.0003 & \\
Level of significance & $\star *$ & \\
\hline
\end{tabular}

Data were analyzed using 't' test

** $=$ Significant at $(p<0.01)$

The difference between the serum magnesium level of the case and the control group was statistically highly significant $(P=<0.001)$ The mean $( \pm S D)$ serum magnesium level of the case group was $1.84 \pm 0.26$ $\mathrm{mg} / \mathrm{dl}$ with a range 1.0 to $2.4 \mathrm{mg} / \mathrm{dl}$ and the mean serum magnesium level of the control group was 2.29 $\pm 0.28 \mathrm{mg} / \mathrm{dl}$ with a range 1.7 to $2.9 \mathrm{mg} / \mathrm{dl}$ (table III). Serum magnesium of eclamptic patient $(1.8063 \mathrm{mg} \pm 0.25)$ was significantly lower than that of
Below 90

90-100

101-110

Above 110

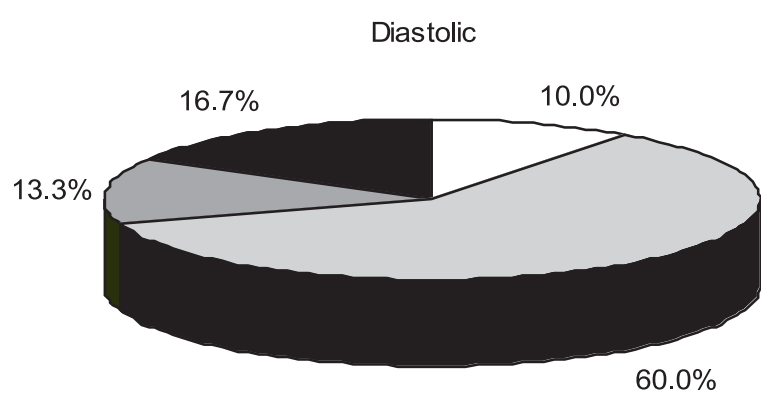

Fig.-1: Status of study group in relation to blood pressure

pre-eclamptic patient $(1.9150 \mathrm{mg} \pm 0.26)$ where $p=<05$ (table IV). Maternal serum magnesium level tends to decrease gradually when the number of para increases in control group. Mean SM level of study group shows lower level with corresponding control group of same parity (table V). It was observed that there is positive relationship between maternal serum magnesium level \& birth weight $(\mathrm{kg})$ of baby where $r=$ correlation coefficient is $0.3544^{\star *}$ (fig-II).

Table III

Serum Magnesium Status of respondents:

\begin{tabular}{llcccccc}
\hline & Respondent Group & N & Mean & SD & Std. Error Mean & Max & Min \\
\hline Serum magnesium & Control Group & 60 & 2.29 & 0.28 & 0.04 & 2.9 & 1.7 \\
Level(mg/dl) & Study Group & 60 & 1.84 & 0.26 & 0.03 & 2.4 & 1.0 \\
P value & 0.0001 & & & & & & \\
Level of significance & $\star \star \star$ & & & & & & \\
\hline
\end{tabular}

Data were analyzed using ' $\mathrm{t}$ ' test

Here $\mathrm{t}=2.0009$

*** =Significant at $(p<0.001)$

Table IV

Serum Magnesium Status of the study group:

\begin{tabular}{llccccc}
\hline & Study Group & $\mathrm{N}$ & Mean & SD & Max & Min \\
\hline Serum magnesium & Pre-eclampsia group & 20 & 1.9150 & 0.26431 & 2.40 & 1.27 \\
Level(mg/dl) & Eclampsia Group & 40 & 1.8063 & 0.25557 & 2.18 & 1.0 \\
& Total & 60 & 1.8425 & 0.26143 & 2.40 & 1.0 \\
P value & 0.04 & & & & & \\
\hline
\end{tabular}

Level of significance *

Data were analyzed using ' $t$ ' test

Here $\mathrm{t}=2.001$

* =Significant at $(p<0.05)$ 
Table-V

Relation of serum magnesium level with parity between control and study group:

\begin{tabular}{llccc}
\hline Parity & \multicolumn{2}{c}{$\begin{array}{c}\text { Control }(\mathrm{N}=60) \\
\text { Mean } \pm \text { SD }(\mathrm{mg} / \mathrm{dl})\end{array}$} & $\%$ & $\begin{array}{c}\text { Study }(\mathrm{N}=60) \\
\text { Mean } \pm \text { SD }(\mathrm{mg} / \mathrm{dl})\end{array}$ \\
\hline 0 & $30(50.00)$ & $2.32 \pm 0.33$ & $25(41.67)$ & $1.82 \pm 0.30$ \\
1 & $17(28.33)$ & $2.26 \pm 0.21$ & $14(23.33)$ & $1.86 \pm 0.24$ \\
2 or more & $13(21.67)$ & $1.84 \pm 0.00$ & $21(35.00)$ & $1.86 \pm 0.14$ \\
Mean \pm SD & & $2.29 \pm 0.17$ & & $1.84 \pm 0.23$ \\
P value & 0.0001 & & & \\
Level of significance & $* *$ & & & \\
\hline
\end{tabular}

Data were analyzed using ' $\mathrm{t}$ ' test

** $=$ Significant at $(p<0.01)$

Note: Figure in the parentheses indicates number of observation.

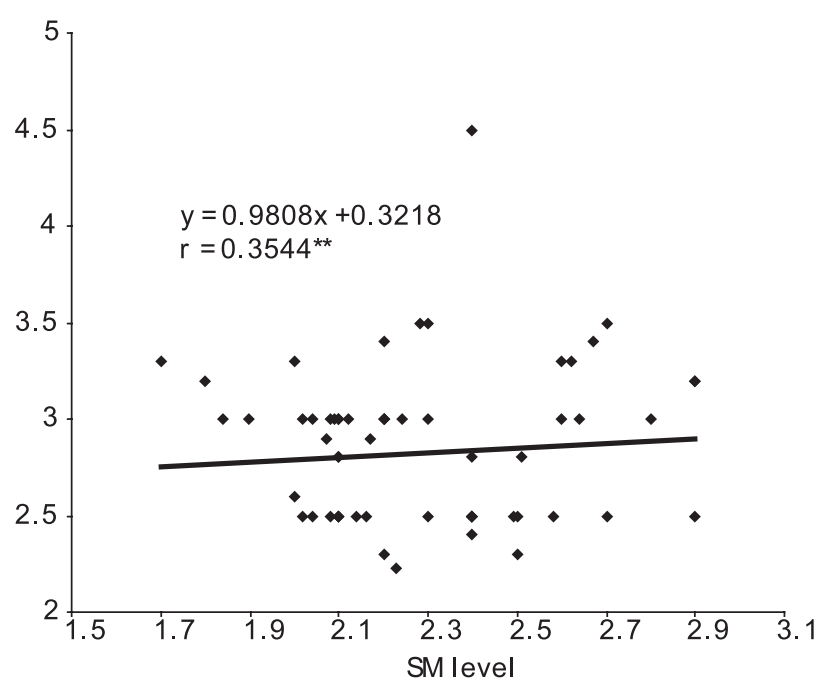

Fig.-2: Relationship between birth weight and mternal serum magnesium level

\section{Discussion}

Pre-eclampsia/eclampsia is the most common serious medical disorder of human pregnancy, which complicates approximately $5-7 \%$ of pregnancy. ${ }^{9}$ Magnesium sulphate halves the risk of eclampsia and reduces the risk of maternal death. ${ }^{10}$

In our study the result shows statistically highly significant difference $(P<0.001)$ of serum magnesium between study and control group. Serum magnesium of eclamptic patient was significantly lower than that of pre-eclamptic patient $(p=<0.05)$. It supported the results of previous studies. Patil and Choudhari showed that statistically significant fall $(p=<0.05)$ in serum magnesium has been observed in preeclampsia and eclampsia. The difference between serum magnesium level of pre-eclampsia and eclampsia is statistically significant $(P=<0.05)^{7}$. Sukonpan and Pfupong found that serum magnesium concentration in pre-eclamptic women was significantly lower than that in normal pregnant women $(p=0.001) .{ }^{11}$ Jain et al. showed that the reduction in serum levels of calcium, magnesium, and zinc during pregnancy might be possible contributors in etiology of pre-eclampsia and supplementation of these elements to diet may be of value to prevent preeclampsia ${ }^{12}$. Idogum, Imarengiaye and Momob observed that there was extracellular calcium and magnesium reduction in patients with pre-eclampsia and eclampsia and reduction may have a cause and effect relationship with these disorders. ${ }^{13}$ The Akther and Rashid reported that abnormally low concentration of ionized magnesium in the serum is responsible for eclamptic convulsion . ${ }^{2}$ Anwary showed in her study which was conducted in BSMMU, the pretreatment magnesium level of eclamptic patient was significantly lower than the control. ${ }^{14}$

In another study conducted by Vahidrodsari et all. in 2008 , the result support the hypothesis on the role of magnesium deficiency in pre-eclampsia pathophysiology and suggest the usefulness of its assessment in the early diagnosis of the disorder. ${ }^{15}$

In Bangladesh the reduction of maternal mortality from eclampsia from 16\% (in 1997) to 8.6\% (1998-2000) occurred due to changing protocol from diazepam to magnesium sulphate for control of convulsion. ${ }^{16}$

This study showed a statistically significant difference between case and control group regarding antenatal care (ANC) status in which $82 \%$ of the study group had no ANC. This result is consistent with one previous study conducted by Akther and Rashid in 2009 where 
$72 \%$ of the study group had no ANC. ${ }^{2}$ The finding of another study was that only $2.3 \%$ women end their pregnancy under medical supervision (whether it be abortion or delivery); the rest have no access to obstetric care. Most of the eclamptic patients are born in rural areas and belong to a lower social class. As a result most have never received antenatal care. ${ }^{16}$ Maternal serum magnesium level tends to decrease gradually when the number of para increases in control group. This findings is very much consistent with the result of a community based cross-sectional study that was conducted in a rural community of Hariana State, India. The finding was that there was a significant decrease $(P=0.01)$ in serum magnesium levels with the increase in parity. ${ }^{8}$

In our study all the eclamptic and severe pre-eclamptic mothers received magnesium sulfate as therapeutic and prophylactic purpose respectively and the outcome was excellent. This result indicate that there was hypomagnesaemic condition developed in these study group which was also observed by the estimation of serum magnesium of the study and control group. So estimation of serum magnesium of pregnant women during antenatal period should be done to detect pre-eclampsia in high risk group and thereby to prevent eclampsia. Oral magnesium preparations should be supplemented during prepregnancy or early pregnancy for prevention of preeclampsia and eclampsia. Routine use of magnesium preparations during antenatal period may improve the neonatal outcome also.

\section{References:}

1. Decherney AH, Nathan L,Goodwin TM, Laufer N.. Current Diagnosis \& Treatment- Obstetrics \& Gynaecology.. Hypertension in pregnancy. $10^{\text {th }}$ edition. Mc Graw Hill, 2007. p-318-326.

2. Akther $R$ and Rashid $M$. Is low level of serum ionized magnesium responsible for eclampsia? Journal of Bangladesh College of Physicians \& Surgeons. Vol-27, no-2, May 2009. p-76-81.

3. Hall DG, Serum Magnesium in Pregnancy, Journal of Obstetrics \& Gynaecology, vol. 9 no 2, February 1957.

4. Swaminathan R, Magnesium Metabolism and its Disorders. The Clinical Biochemist Reviews, vol. 24, no.2; 47-66, May 2003.

5. Park K. Park's Text Book of Preventive And Social Medicine.15th edition, pp-192-438.
6. Begum HA, Shamsuddin L and Khatun S. Relationship of Preterm Labour with Serum Magnesium Level. Bangladesh J Obstet Gynaecol, 2004. vol. 19, no. 1 pp 3-6.

7. Patil VP and Choudhary NA, A Study of Serum Magnesium in Pre-eclampsia \& Eclampsia. Indian Journal of Clinical Biochemistry. 1991. vol. 6, pp 69-72.

8. Pathak P, Kapoor SK, Kapil U and Dwivedi SN. Serum Magnesium Level among Pregnant Women in a Rural Community of Haryana State, India. European Journal of Clinical Nutrition,2003, 57, 1504- 1506.

9. Hoque MM, Bulul T, Mahal M, Islam NAF and Ferdousi M , Serum Homocysteine in Preeclampsia \& Eclampsia, Bangladesh Medical Research Council Bulletine, 2008, 34: 16- 20.

10. The Magpie Trial Collaboration Group, Do women with pre-eclampsia \& their babies benefit from magnesium sulphate?, The Lancet, 2002, vol. 359, 1877- 1890.

11. Sukonpan K, and Phupong V, Serum Calcium and Serum Magnesium in Normal and Preeclamptic Pregnancy,Archieves of Gynaecology and Obstetrics, 2004, vol. 273, no. 1, pp 12-16.

12. Jain S, Sharma P, Kulshreshtha S, Mohan G, Singh S, The Role of Calcium, Magnesium and Zinc in Pre-eclampsia, Biological Trace Element Research, June 2009, (http://www.springerlink. com/content/517844530370xv22/).

13. Idiogum ES, Imerengiaye CO and Momob SM, Extracellular Calcium \& Magnesium in Preeclampsia and Eclampsia, African Journal of Reproductive Health, May 2010.(http:// www.jstor.org/pss/25549719).

14. Anwary SA, Serum Magnesium Level in Eclamptic Patients, MS Thesis, Dhaka Univerdity, Dhaka, pp 54-66.

15. Vahidrodsari F, Ayaty S, Tourabizadeh A, AyatAllahi $\mathrm{H}$, Esmaeli $\mathrm{H}$ and Shahabian $\mathrm{M}$. Serum Calcium and Magnesium in Preeclamptic and Normal Pregnancy; A Comperative Study. Journal of Reproduction and Infertility, 2008, vol. 9, no. 36, pp-1-3.

16. Begum et al. Eclampsia still a Problem in Bangladesh, Medscape General Medicine, 2004, vol. 6 , no. $4 ; 52$. 